\title{
Export-oriented intensification of potato production in the central non-chernozem region of Russia
}

\author{
Z.I. Usanova, S.P. Migulev, and M.N. Pavlov* \\ FSBEI HE Tver SAA, Tver, Russia
}

\begin{abstract}
The results of studies (2019-2020) in a two-factor field experiment on sod-podzolic light-loamy well-cultivated soil on the of study the effect of non-root fertilization on the productivity of potato varieties are presented. The following factors were studied: A - Variety: 1 - Colomba, 2 - Red Scarlett, 3 - Gala. B - Preparation for foliar dressing: 1 - Control (water, $300 \mathrm{l} / \mathrm{ha}$ ), 2 - Zircon (30 ml/ha), 3 - Epin-Extra (15 $\mathrm{ml} / \mathrm{ha}$ ), 4 - Folirus Premium (7 1/ha), 5 - Aquamix (220 g/ha), 6 - Mixture of $\mathrm{Zn}$-EDDA $+\mathrm{Cu}-$ EDDA complexates (7 l/ha). It was revealed that the Red Scarlett variety had the highest productivity. Methods have been developed to increase the productivity of potato varieties by using the growth regulator Zircon, which provides the highest yield of dry matter and starch (an increase of 19.3 and $18.9 \%$ to the control), and fertilizers mixture of $\mathrm{Zn}$-EDDA + $\mathrm{Cu}$ EDDA complexates (an increase of 14.4 and $11.8 \%$ to the control).
\end{abstract}

\section{Introduction}

Potato (Solanum tuberosum L.) is one of the most important food, technical and forage plants. Its tubers have a valuable chemical composition [1,2]. They contain about $25 \%$ of dry substances, including $14 \ldots 22 \%$ starch, $1.4 \ldots 3.0 \%$ protein, about $1 \%$ fiber, $0.2 \ldots 0.3 \%$ fat and $0.8 \ldots 1.0 \%$ ash substances [2].

Obtaining high-quality tubers will help to strengthen Russia's food security and increase the export attractiveness of products. The main way to solve these problems is to create innovative technologies for the production of agricultural products, including potatoes, that meet the established environmental and sanitary-epidemiological requirements, which will provide the population with high-quality and safe food products [3].

They are based on the cultivation of high-yielding varieties and the use of modern cultivation techniques and technologies adapted to the conditions of a particular region [2]. The genetic potential of the potato variety is of great importance in increasing the productivity of agrocenoses, as well as the resistance of plants to biotic and abiotic environmental factors, including diseases, pests, stressful situations [4,5]. An important way to improve technologies is the use of various new plant growth regulators and

* Corresponding author: maxnipav@gmail.com 
stimulators and complex fertilizers in the form of foliar fertilizing. They require lower costs for application but contribute to a significant increase in the quantity and quality of the yield [6].

\section{Materials and methods}

The purpose of our research is to improve the technology of cultivating potato varieties by using foliar dressing with growth regulators, chelate compounds, complex fertilizers; to identify the most effective technology options in the conditions of the Central NonChernozem region of Russia.

The research was carried out in a two-factor field experiment at the experimental field of the Tver State Agricultural Academy in 2019-2020 on sod-medium-podzolic residual carbonate gleyish soil on a moraine, light-loamy in granulometric composition, well cultivated.

In the experiment, the following was studied: Factor $A$ - Variety: 1 - Colomba, 2 - Red Scarlett, 3 - Gala. Factor B - Preparation for foliar dressing: 1 - Control (water treatment, 300 1/ha), 2 - Zircon (30 ml/ha), 3 - Epin-Extra (15 ml/ha), 4 - Folirus Premium (7 1/ha), 5 Aquamix (220 g/ha), 6 - Mixture of Zn-EDDA + Cu - EDDA (ethylene diamine disuccinic acid) (solution) complexates ( 7 1/ha).

The treatment with the preparations was carried out twice: at the height of potato plants $20-25 \mathrm{~cm}$ (1.07) and at the beginning of budding (20.07). The area of the accounting plot according to factor $\mathrm{A}$ is $56 \mathrm{~m}^{2}$, according to factor $\mathrm{B}-14 \mathrm{~m}^{2}$. The repetition in the experiment is 3 -fold.

Objects of research - potato varieties:

1. Colomba. Originators: HZPC Holland B.V. Very early variety, for table purposes. The plant is of medium height, leaf type, semi-erect to branchy. The tuber is oval-rounded with a yellow peel and pulp.

2. Red Scarlett. Originators: HZPC Holland B.V., CJSC Oktyabrskoye, LLC Alchak, etc. Early-ripening, for table purposes. The plant is low, intermediate type, semi-erect. The tuber is elongated-oval, the peel is red, the pulp is yellow.

3. Gala. Originator: NORIKA. High-quality medium-early table variety with oval and elongated oval tubers, with small eyes. The peel is smooth, yellow. The pulp is dark yellow $[2]$.

The laying of the experiment, the determination of the quality of the tuber harvest, the accounting of the harvest, as well as the mathematical processing of the results were carried out according to existing methods $[7,8]$. In the experiment, the recommended technology was used for cultivation with row spacing of $70 \mathrm{~cm}$ and doses of fertilizers for food potatoes.

The weather conditions of 2019 were characterized by hot and dry May, 1 and 2 decades of June, cold July and 1 decade of August. In general, during the growing season, the sum of temperatures and precipitation were close to the average annual norm.

The year 2020 was characterized by a cool and humid May, a warm and dry June, and wet but close to normal temperatures in July and August. In general, during the growing season, the sum of temperatures and precipitation were higher than the average annual norm.

\section{Results and discussion}

It was revealed that the passage of potato plant development phases and the duration of interphase periods depend more on the variety than on other factors studied. Shoots in all 
varieties occurred on June 15 - 17; budding - in the varieties Colomba and Gala on June 29 - July 9, in the variety Red Scarlett - July 2 - July 15; flowering and defloration were observed only in 2020 - on July 14 and 24 in all varieties.

The studied preparations had a greater impact on yield than the varieties (Table 1).

Table 1. Yield of potato varieties, $t / h a$, average for 2019-2020.

\begin{tabular}{|c|c|c|c|c|c|c|}
\hline \multirow{2}{*}{} & \multicolumn{3}{|c|}{ Variety, group of ripeness } & \multicolumn{2}{c|}{ To control } \\
\cline { 2 - 7 } & & & & & \\
Foliar dressing & $\begin{array}{c}\text { Colomba, } \\
\text { 01 Control }\end{array}$ & $\begin{array}{c}\text { Red } \\
\text { Scarlett, } \\
03\end{array}$ & $\begin{array}{c}\text { Gala, } \\
04\end{array}$ & Average & \pm & $\%$ \\
\hline Water (control) & 26.6 & 26.5 & 28.2 & 27.1 & 0.0 & 100.0 \\
\hline Zircon & 29.3 & 31.4 & 30.8 & 30.5 & 3.4 & 112.5 \\
\hline Epin - extra & 26.7 & 30.3 & 30.7 & 29.3 & 2.2 & 108.0 \\
\hline Folirus-Premium & 27.2 & 29.9 & 28.3 & 28.5 & 1.4 & 105.2 \\
\hline Aqua-Mix & 29.4 & 29.9 & 28.6 & 29.3 & 2.2 & 108.1 \\
\hline $\begin{array}{c}\text { Zn-EDDA + Cu } \\
\text { EDDA }\end{array}$ & 31.0 & 31.5 & 30.1 & 30.9 & 3.8 & 114.0 \\
\hline Average & 28.4 & 29.9 & 29.5 & 29.2 & & \\
\hline LSD05 for the variety & & & & & & \\
\hline $\begin{array}{c}\text { LSD05 for the } \\
\text { preparation }\end{array}$ & & & & & & \\
\hline
\end{tabular}

The varieties reacted differently to the type of dressing. Thus, in the Colomba variety, the greatest tuberous productivity was provided by fertilizing with a mixture of $\mathrm{Zn}$ - EDDA $+\mathrm{Cu}-$ EDDA complexates, in the Red Scarlett variety - with a Zircon preparation and a mixture of complexates, in the Gala variety - growth regulators Zircon and Epin - extra. On average, for varieties, the highest yield from growth regulators was provided by Zircon (an increase of $12.5 \%$ to the control), from fertilizers - a mixture of Zn-EDDA + Cu EDDA complexates (an increase of $14.0 \%$ to the control).

According to the total collection of tubers per hectare, the Red Scarlett variety had an advantage, which provided an increase in yield to the Colomba variety $-1.5 \mathrm{t} / \mathrm{ha}$, which is higher than $\operatorname{LSD}_{05}(1.1 \mathrm{t} / \mathrm{ha})$.

The use of various growth regulators and fertilizers in potato cultivation technology has a different effect on the quality of the crop under different environmental conditions $[9,10,11]$.

Physical and biochemical evaluation of tubers of different varieties grown in variants with treatment with the studied preparations showed that the crop quality corresponds to the biological potential, the purpose of the variety and depends on the type of preparation used. At the same time, the reaction of different varieties to foliar fertilizing is not the same (Table 2).

Table 2. The yield quality of different potato varieties, depending on the use of foliar fertilizing, average for 2019-2020.

\begin{tabular}{|c|c|c|c|c|}
\hline Variety & Preparation & Dry matter, \% & $\begin{array}{c}\text { Crude protein, } \\
\text { \% a.d.m. }\end{array}$ & Starch, \% \\
\hline \multirow{2}{*}{ Colomba } & Water (control) & 18.3 & 8.4 & 12,9 \\
\cline { 2 - 5 } & Zircon & 18.4 & 8.9 & 11,8 \\
\hline
\end{tabular}




\begin{tabular}{|c|c|c|c|c|}
\hline & Epin - extra & 18.4 & 8.6 & 12,2 \\
\hline & Folirus-Premium & 16.7 & 9.2 & 10,8 \\
\hline & Aqua-Mix & 16.5 & 9.8 & 10,6 \\
\hline & $\mathrm{Zn}-\mathrm{EDDA}+\mathrm{Cu}$ EDDA & 16.4 & 10.3 & 10,2 \\
\hline \multicolumn{2}{|c|}{ Average for variety } & 17,5 & 9.2 & 11.4 \\
\hline \multirow{6}{*}{$\begin{array}{c}\text { Red } \\
\text { Scarlett }\end{array}$} & Water (control) & 18.7 & 10.5 & 13,8 \\
\hline & Zircon & 21.0 & 8.8 & 14,2 \\
\hline & Epin - extra & 17.8 & 10.8 & 12,4 \\
\hline & Folirus-Premium & 18.0 & 11.8 & 13,1 \\
\hline & Aqua-Mix & 18.7 & 11.1 & 12,2 \\
\hline & $\mathrm{Zn}-\mathrm{EDDA}+\mathrm{Cu}$ EDDA & 19.5 & 10.1 & 13,0 \\
\hline \multicolumn{2}{|c|}{ Average for variety } & 18,9 & 10.5 & 13.1 \\
\hline \multirow{6}{*}{ Gala } & Water (control) & 16.1 & 11.3 & 9,1 \\
\hline & Zircon & 16.9 & 10.5 & 11,6 \\
\hline & Epin - extra & 17.9 & 11.4 & 11,2 \\
\hline & Folirus-Premium & 17.1 & 11.0 & 11,2 \\
\hline & Aqua-Mix & 17.4 & 10.1 & 11,0 \\
\hline & $\mathrm{Zn}-\mathrm{EDDA}+\mathrm{Cu}$ EDDA & 17.3 & 11.2 & 11,7 \\
\hline \multicolumn{2}{|c|}{ Average for variety } & 17,1 & 10.9 & 11.0 \\
\hline \multirow{6}{*}{$\begin{array}{l}\text { Average } \\
\text { for } \\
\text { varieties }\end{array}$} & Water (control) & 17.7 & 10.1 & 11,9 \\
\hline & Zircon & 18.7 & 9.4 & 12,5 \\
\hline & Epin - extra & 18.1 & 10.3 & 12,0 \\
\hline & Folirus-Premium & 17.3 & 10.7 & 11,7 \\
\hline & Aqua-Mix & 17.5 & 10.3 & 11,3 \\
\hline & $\mathrm{Zn}-\mathrm{EDDA}+\mathrm{Cu}$ EDDA & 17.7 & 10.5 & 11,6 \\
\hline \multicolumn{2}{|c|}{ Average for experiment } & 17,8 & 10.2 & 11.8 \\
\hline
\end{tabular}

The plant dry matter, as is known, consists of organic and mineral compounds and is one of the simplest indicators of crop quality [8]. In potato, the main reserve carbohydrate and the main component of the dry matter is a polysaccharide - starch [2,11]. In the Colomba variety, foliar dressing was slightly increased by growth regulators, and the dry matter content in the tubers was reduced by various types of fertilizers.

The Red Scarlett variety showed an increase in the content of dry matter and starch in tubers when using the preparation Zircon, respectively, by 2.3 and $0.4 \%$, and in the Gala variety - from the use of Epin-Extra, Aquamix and Zn-EDDA + Cu EDDA, respectively, by $1.8,1.3$ and $1.2 \%$. The use of all preparations in dressing of this variety contributes to an increase in the amount of starch in tubers by $1.9-2.6 \%$.

The amount of raw protein in tubers is an important characteristic of their nutritional value [2]. We have revealed the unequal influence of foliar dressing on this indicator in different varieties. Thus, the greatest increase in the amount of crude protein was noted: in the Colomba variety from treatment with Aqua-Mix and Zn-EDDA + $\mathrm{Cu}$ EDDA (by 1.4$1.9 \%$ ), in the Red Scarlett variety - Folirus-Premium (by $1.3 \%$ ). The Gala variety did not respond to the use of all preparations by changing the crude protein. 
An integrated indicator for assessing the productivity and quality of potato agrocenoses products is the collection of nutrients with the harvest of tubers [12]. We have identified the dependence of this indicator on both the content of these substances in tubers and on the yield of the variety (Table 3 ).

Table 3. The yield of nutrients per hectare of different potato varieties, depending on the use of foliar fertilizing, the average for 2019-2020.

\begin{tabular}{|c|c|c|c|c|}
\hline \multirow[t]{2}{*}{ Variety } & \multirow[t]{2}{*}{ Preparation } & \multicolumn{3}{|c|}{ Yield, c/ha } \\
\hline & & Dry matter & Crude protein & Starch \\
\hline \multirow[t]{6}{*}{ Colomba } & Water (control) & 48.9 & 1.55 & 34,3 \\
\hline & Zircon & 53.8 & 1.64 & 34,5 \\
\hline & Epin - extra & 49.1 & 1.58 & 32,7 \\
\hline & Folirus-Premium & 45.6 & 1.55 & 29,3 \\
\hline & Aqua-Mix & 48.6 & 1.62 & 31,2 \\
\hline & $\mathrm{Zn}-\mathrm{EDDA}+\mathrm{Cu}$ EDDA & 50.9 & 1.68 & 31,5 \\
\hline \multicolumn{2}{|c|}{ Average for variety } & 49,6 & 1.61 & 32.4 \\
\hline \multirow[t]{6}{*}{ Red Scarlett } & Water (control) & 49.6 & 1.96 & 36,5 \\
\hline & Zircon & 65.8 & 1.83 & 44,5 \\
\hline & Epin - extra & 54.1 & 1.93 & 37,6 \\
\hline & Folirus-Premium & 53.8 & 2.12 & 39,4 \\
\hline & Aqua-Mix & 55.7 & 2.07 & 36,5 \\
\hline & $\mathrm{Zn}-\mathrm{EDDA}+\mathrm{Cu}$ EDDA & 61.5 & 1.97 & 41,0 \\
\hline \multicolumn{2}{|c|}{ Average for variety } & 56,7 & 1.99 & 39.3 \\
\hline \multirow[t]{6}{*}{ Gala } & Water (control) & 45.4 & 1.83 & 25,6 \\
\hline & Zircon & 52.0 & 1.77 & 35,6 \\
\hline & Epin - extra & 55.2 & 2.04 & 34,5 \\
\hline & Folirus-Premium & 48.4 & 1.88 & 31,8 \\
\hline & Aqua-Mix & 49.6 & 1.75 & 31,3 \\
\hline & $\mathrm{Zn}-\mathrm{EDDA}+\mathrm{Cu}$ EDDA & 52.1 & 1.93 & 35,3 \\
\hline \multicolumn{2}{|c|}{ Average for variety } & 50,4 & 1.87 & 32.3 \\
\hline \multirow{6}{*}{$\begin{array}{l}\text { Average for } \\
\text { varieties }\end{array}$} & Water (control) & 47.9 & 1.78 & 32,1 \\
\hline & Zircon & 57.2 & 1.75 & 38,2 \\
\hline & Epin - extra & 52.8 & 1.85 & 34,9 \\
\hline & Folirus-Premium & 49.3 & 1.85 & 33,5 \\
\hline & Aqua-Mix & 51.3 & 1.81 & 33,0 \\
\hline & $\mathrm{Zn}-\mathrm{EDDA}+\mathrm{Cu}$ EDDA & 54.8 & 1.86 & 35,9 \\
\hline \multicolumn{2}{|c|}{ Average for experiment } & 52,2 & 1.82 & 34.6 \\
\hline
\end{tabular}

The highest yield of dry matter was distinguished by the Red Scarlett variety, which surpassed other varieties by $6.3-7.1 \mathrm{c} /$ ha in this indicator. It also had an advantage in the yield of crude protein and starch: by $0.12-0.38$ and $6.9-70 \mathrm{c} / \mathrm{ha}$, respectively. The high 
yield of nutrients per hectare of plantings in this variety is explained by their maximum accumulation in tubers.

Fertilizers and growth regulators in most variants provided an increase in the yield of nutrients per hectare of plantings. According to the types of foliar dressing, the highest yield of dry matter and starch from growth regulators was provided by Zircon (on average for varieties 57.2 and $38.2 \mathrm{t} / \mathrm{ha}$, an increase in control of 19.3 and $18.9 \%$ ), from fertilizers a mixture of Zn-EDDA + Cu EDDA complexates (on average for varieties 54.8 and 35.9 t/ha, an increase in control of 14.4 and $11.8 \%$ ). The increase in the yield of nutrients in these variants in the Red Scarlett and Gala varieties is due to high yield along with their maximum accumulation in tubers, in the Colomba variety - only an increase in yield.

This pattern is typical for all varieties, except for the Gala variety, which has the highest yield of dry matter when using the preparation Epin-extra, which is due to an increase in its amount in tubers.

Of the growth regulators, the highest yield of crude protein was provided by the preparation Epin - extra $(1.85 \mathrm{c} / \mathrm{ha}$, an increase of $4.1 \%$ to the control), from fertilizers - a mixture of $\mathrm{Zn}$ EDDA + Cu EDDA complexates $(1.86 \mathrm{t} / \mathrm{ha}$, an increase of $4.8 \%$ to the control). In the first case, this is due to an increase in the content of crude protein in tubers, in the second - an increase in yield.

\section{Conclusions}

In the conditions of 2019-2020 in the Central Non-Chernozem Region of Russia, the earlyripening Red Scarlett variety had the highest productivity. The maximum yield of this variety and potato on average by varieties, as well as the best quality of the crop and the highest yield of nutrients per hectare was provided by foliar fertilizing with the growth regulator Zircon and a mixture of Zn-EDDA + $\mathrm{Cu}$ EDDA complexates.

Effective methods of increasing the productivity and quality of the crop of different potato varieties are the use of the growth regulator Zircon, which provides the highest yield of dry matter and starch per hectare (an increase of 19.3 and $18.9 \%$ to the control), as well as chelated compounds $\mathrm{Zn}-\mathrm{EDDA}+\mathrm{Cu}$ EDDA (an increase of 14.4 and $11.8 \%$ to the control).

\section{References}

1. G.S. Posypanov, V.E. Dolgodvorov, B.Kh. Zherukov, etc. Crop production, 612 (Moscow: SIC INFRA-M, 2015)

2. Z.I. Usanova, A.K. Oserbaev, K.I. Ziyaev, M.N. Pavlov, Tubers. Biological features and technologies of potato and ground pear cultivation, 150 (Tver: Tver SAA, 2018)

3. The Doctrine of food security of the Russian Federation, Decree of the President of the Russian Federation No. 20 dated January 21, 2020 "On approval of the Food Security Doctrine of the Russian Federation". URL: https://www.garant.ru/products/ipo/prim e/doc/73338425/

4. W.W. Kirk, Ann. Appl. Biol. 3, 511-525 (1992)

5. D.E. Zaag, J.A. De Bokx, P. Oosterveld, F. Quak, J.P.H. van der Want Growing seed potatoes, Viruses of potatoes and seed-potato production Pudoc, 176-203 (Wageningen, 1987)

6. Z.I. Usanova, S.E. Pryadein, Potatoes and vegetables 6, 27-31 (2020) https://doi.org/10.25630/PAV.2020.73.35.004

7. B.A. Dospekhov, Methods of field experience, 351 (Moscow, 1985) 
8. Z.I. Usanova, Methods of performing scientific research on crop production, 143 (Tver, Tver SAA, 2015)

9. B.B. Dean, Managing the Potato Production System, 734, 202 (2018)

10. E. Stashevsky, O.A. Kuzminova, S.G. Vologin et al., Agriculture 6, 43-48 (2019)

11. C.O. Obiero, S.P. Milroy, R.W. Bell, Environmental and Experimental Botany 162, 560-571 (2019)

12. A.O. Grankina, A.F. Peliy, V.V. Nosov, V.V. Demidov, M.V. Sterkin, Potatoes and vegetables 7, 26-28 (2021) 